\title{
GPCR-Based Bioactive Peptide Screening Using Phage-Displayed Peptides and an Insect Cell System for Insecticide Discovery
}

\author{
Man-Yeon Choi ${ }^{1, *}$ (D) and Robert K. Vander Meer ${ }^{2}$ \\ 1 USDA-ARS, Horticultural Crops Research Laboratory, Corvallis, OR 97330, USA \\ 2 USDA-ARS, Center for Medical, Agricultural, and Veterinary Entomology, Gainesville, FL 32608, USA; \\ bob.vandermeer@usda.gov \\ * Correspondence: man-yeon.choi@usda.gov
}

Citation: Choi, M.-Y.; Vander Meer, R.K. GPCR-Based Bioactive Peptide Screening Using Phage-Displayed Peptides and an Insect Cell System for Insecticide Discovery. Biomolecules 2021, 11, 583. https://doi.org/ 10.3390/biom11040583

Academic Editor: Dov Borovsky

Received: 26 February 2021

Accepted: 13 April 2021

Published: 16 April 2021

Publisher's Note: MDPI stays neutral with regard to jurisdictional claims in published maps and institutional affiliations.

Copyright: (C) 2021 by the authors. Licensee MDPI, Basel, Switzerland. This article is an open access article distributed under the terms and conditions of the Creative Commons Attribution (CC BY) license (https:// creativecommons.org/licenses/by/ $4.0 /)$.

\begin{abstract}
The discovery of new insecticides improves integrated pest management (IPM), but is usually a long high-risk process with a low probability of success. For over two decades, insect neuropeptides (NPs) and their G-protein coupled receptors (GPCRs) have been considered as biological targets for insect pest control, because they are involved in almost all physiological processes associated with insect life stages. A key roadblock to success has been the question of how large volume chemical libraries can be efficiently screened for active compounds. New genomic and proteomic tools have advanced and facilitated the development of new approaches to insecticide discovery. In this study, we report a novel GPCR-based screening technology that uses millions of short peptides randomly generated by bacteriophages, and a method using an insect Sf9 cell expression system. The fire ant is a good model system, since bioactive peptides have been identified for a specific GPCR. The novel small peptides could interfere with the target GPCR-ligand functions. Therefore, we refer to this new mechanism as "receptor interference" (RECEPTORi). The GPCR-based bioactive peptide screening method offers multiple advantages. Libraries of phage-displayed peptides ( $\sim 10^{9}$ peptides) are inexpensive. An insect cell-based screening system rapidly leads to target specific GPCR agonists or antagonists in weeks. Delivery of bioactive peptides to target pests can be flexible, such as topical, ingestion, and plant-incorporated protectants. A variety of GPCR targets are available, thus minimizing the development of potential insecticide resistance. This report provides the first proof-of-concept for the development of novel arthropod pest management strategies using neuropeptides, and GPCRs.
\end{abstract}

Keywords: GPCR; neuropeptide; bioactive peptides; phage-displayed peptides; biopanning; insect cell expression; insecticide discovery; RECEPTORi

\section{Introduction}

The discovery of new insecticides is a long iterative process with high risk and low chances of success [1]. An efficient screening process using large volume chemical libraries, including natural products, is required. It is anticipated that the discovery of novel biologically-based insecticides will be facilitated with technological advancements, such as '-omics' tools. A variety of insect genomes (https://i5k.nal.usda.gov, accessed on 2 February 2020) and RNA sequences are currently available and offer great potential for a genome-based approach for characterizing target G-protein-coupled receptors (GPCRs). This approach, coupled with a technique to screen chemical libraries, is exciting and holds promise for the identification of small pharmacological compounds for pest control [2-4].

Most insect neuropeptides (NPs) activate GPCRs, which are involved in a variety of critical physiological processes at all insect life stages, including fat body homeostasis, feeding, digestion, excretion, circulation, reproduction, metamorphosis, and behavior [5-7]. For over two decades, insect NPs and their GPCRs have been proposed as potential targets 
for next-generation pest management $[8,9]$. The development of GPCR-based assays is dependent on the expression of the targeted GPCR in a recombinant cell system. Ligand binding strength to the GPCRs can be measured by fluorescence intensities induced by second messengers such as $\mathrm{Ca}^{2+}$ or cAMP molecules in the cells.

One major insect neuropeptide family is the PRXamide $\left(\mathrm{NH}_{2}\right)$ peptide family $(\mathrm{X}=\mathrm{a}$ variable amino acid). The peptide family is well-characterized with a common amino acid sequence, PRXamide, at the C-terminal end, which is conserved across animal groups [10]. Data mining and computational analysis from the Drosophila genome identified three GPCRs (CG8784, CG8795, CG9918) for PRXamide peptides that are orthologs to the vertebrate neuromedin U receptor (NmU-R) [11,12]. The hypothesis of ligand-receptor coevolution was supported when GPCRs of Drosophila PRXamide peptides were first identified and found to be evolutionarily related to the vertebrate peptide, $\mathrm{NmU}[13,14]$. Since then, many GPCRs and their PRXamide ligands have been identified from other insect groups, and have a variety of biological functions [10], e.g., pheromone biosynthesis by the pheromone biosynthesis activating neuropeptide (PBAN), diapause by the diapause hormone (DH), ecdysis by the ecdysis triggering hormone (ETH), and muscle contraction by the pyrokinin (PK) peptide.

Therefore, the PRXamide peptides/receptors are considered good targets for pest control. For example, genes of the PRXamide peptides and their GPCRs from insect pests were selected as RNA interference (RNAi) targets [15-17]. In the present study, we used the fire ant as a model system, because the PBAN/PK peptides and their cognate receptor have been well characterized in the fire ant [18]. A novel GPCR-based biopanning technology was developed using an insect cell system expressing the target GPCR to screen small peptides from phage-displayed peptide libraries, based on their binding to the target GPCR. In our proof-of-concept research, small peptides were isolated and identified that act on the GPCR of the PBAN. The small peptides could interfere with the target GPCR-ligand function. We refer to this new mechanism as "receptor interference" (RECEPTORi). The research reported here illustrates how our innovative methodology can rapidly lead to the development of novel arthropod pest management tools using neuropeptides and their GPCRs. This RECEPTORi technology can be extended to other GPCRs and pests in the future.

\section{Materials and Methods}

\subsection{Insects, Cloning and Expression of the GPCR, and Binding Assay}

The fire ant, Solenopsis invicta, samples were from monogyne (single functional queen) colonies collected in the Gainesville, FL USA area by nest excavation or by rearing colonies from newly mated queens. All colonies were maintained as described previously [19].

After total RNA was isolated from fire ant adults and the cDNA was synthesized, all procedures for cloning the fire ant GPCR PRXamide peptide were followed as previously described [18]. The GPCR gene was ligated into a pIB/V5-His TOPO expression vector (Thermo Fisher Scientific, Waltham, MA, USA).

The functional expression of the GPCR in Sf9 cells, and subsequent binding assays were followed as previously described $[18,20]$. Five micrograms of pIB/GPCR plasmid and $15 \mu \mathrm{L}$ of Cellfectin II reagent (Thermo Fisher Scientific, Waltham, MA, USA) were diluted into $500 \mu \mathrm{L}$ of serum free Insectagro Sf9 medium (Corning, Corning, NY, USA) and allowed to incubate for $10 \mathrm{~min}$ at room temperature, after which they were mixed together and allowed to incubate for an additional 15-20 min. The pIB/GPCR cellfectin mixture was then added to T-25 cell culture flasks containing Sf9 cells at 50\% confluency and incubated overnight at $28{ }^{\circ} \mathrm{C}$. The following morning, the media was removed from each flask and replaced with media containing $20 \mu \mathrm{g} / \mathrm{mL}$ of blasticidin (Corning, Corning, NY, USA). Each transfected cell line was cultured in the presence of $20 \mu \mathrm{g} / \mathrm{mL}$ of blasticidin for approximately three weeks until a blasticidin-resistant cell line was established, then the blasticidin concentration was reduced to $10 \mu \mathrm{g} / \mathrm{mL}$ and the cell lines were frozen until use. 


\subsection{Screening of Small Peptides Using Phage Display and Biopanning}

The procedure for the screening of small peptides [21,22] includes 8 Steps.

Step 1: Removal of non-specific phages. A $10 \mu \mathrm{L}$ Ph.D.-C7C phage library $\left(\sim 2 \times 10^{8}\right.$ phage-displayed peptides (New England Biolabs, Ipswich, MA, USA) was transferred into a $1.5 \mathrm{~mL}$ tube, and incubated with Sf9 cells $\left(\sim 2 \times 10^{6}\right.$ non-transfected cells) at room temperature for $30 \mathrm{~min}$. Then, the phages bound to the Sf9 cells were collected by centrifugation, at $10,000 \times g$ for $10 \mathrm{~min}$ at $4{ }^{\circ} \mathrm{C}$. The supernatant containing the unbound phages was saved for the next step.

Step 2: Isolation of phages binding to the GPCR. The phage supernatant from Step 1 was transferred to a $1.5 \mathrm{~mL}$ tube containing Sf9 cells $\left(\sim 2 \times 10^{6}\right)$ expressing the PBAN GPCR, and incubated at room temperature for $1 \mathrm{~h}$. Then, specific phage peptides bound to Sf9 cells expressing the GPCR were collected along with the cells by centrifugation, at $10,000 \times g$ for $10 \mathrm{~min}$ at $4{ }^{\circ} \mathrm{C}$.

Step 3: Separation of bound phages from the Sf9 cells expressing the GPCR. The supernatant from Step 2 was decanted to collect the cell pellet containing phages bound to the GPCR expressed by the Sf9 cells. The cell pellet was resuspended in $50 \mathrm{mM}$ glycine- $\mathrm{HCl}$ ( $\mathrm{pH}$ 2.2) and incubated at room temperature for $10 \mathrm{~min}$ with shaking to separate the phages from the Sf9 cells. Forty-five microliters of $1 \mathrm{M}$ Tris- $\mathrm{HCl}(\mathrm{pH}$ 9.0) were added to neutralize the phage solution.

Step 4: Transfection of phages into E. coli. The phage solution was added into $20 \mathrm{~mL}$ of a preincubated (OD 0.4-0.6 at $600 \mathrm{~nm}$ ) E. coli culture (K12 ER2738 strain, New England Biolabs, Ipswich, MA, USA) that contained $20 \mu \mathrm{g} / \mathrm{mL}$ of tetracycline. Then, the E. coli culture was incubated at $37^{\circ} \mathrm{C}$ for $4.5 \mathrm{~h}$ with vigorous shaking.

Step 5: Amplification of phages. After $4.5 \mathrm{~h}$ of incubation, the cell culture was centrifuged at $10,000 \times g$ for $10 \mathrm{~min}$ at $4{ }^{\circ} \mathrm{C}$, then the supernatant was collected and transferred to a fresh tube.

Step 6: Harvesting phages. A solution of polyethylene glycol 800 (20\%) (SigmaAldrich, St. Louis, MO, USA) containing $2.5 \mathrm{M} \mathrm{NaCl}$ was added to the supernatant of Step 5 , mixed, and then incubated on ice for $2 \mathrm{~h}$.

Step 7: Isolation of phages. The solution from Step 6 was centrifuged at $10,000 \times g$ for 20 min at $4{ }^{\circ} \mathrm{C}$, and the collected pellet was resuspended in a standard phosphate buffered saline (PBS) with $15 \%$ glycerol and was used for the next round of screening.

Steps 1 to 7 were repeated 3-4 times using the isolated phages from Step 7.

Step 8: Selection of phage colonies. After the 4th round, 20 or more phage colonies were selected and cultured in E. coli to amplify the phages (Figure 1). The purified phage DNAs from the culture were sequenced (Interdisciplinary Center for Biotechnology Research, ICBR, University of Florida, Gainesville, FL, USA) to identify nucleotide sequences encoding the peptides. 


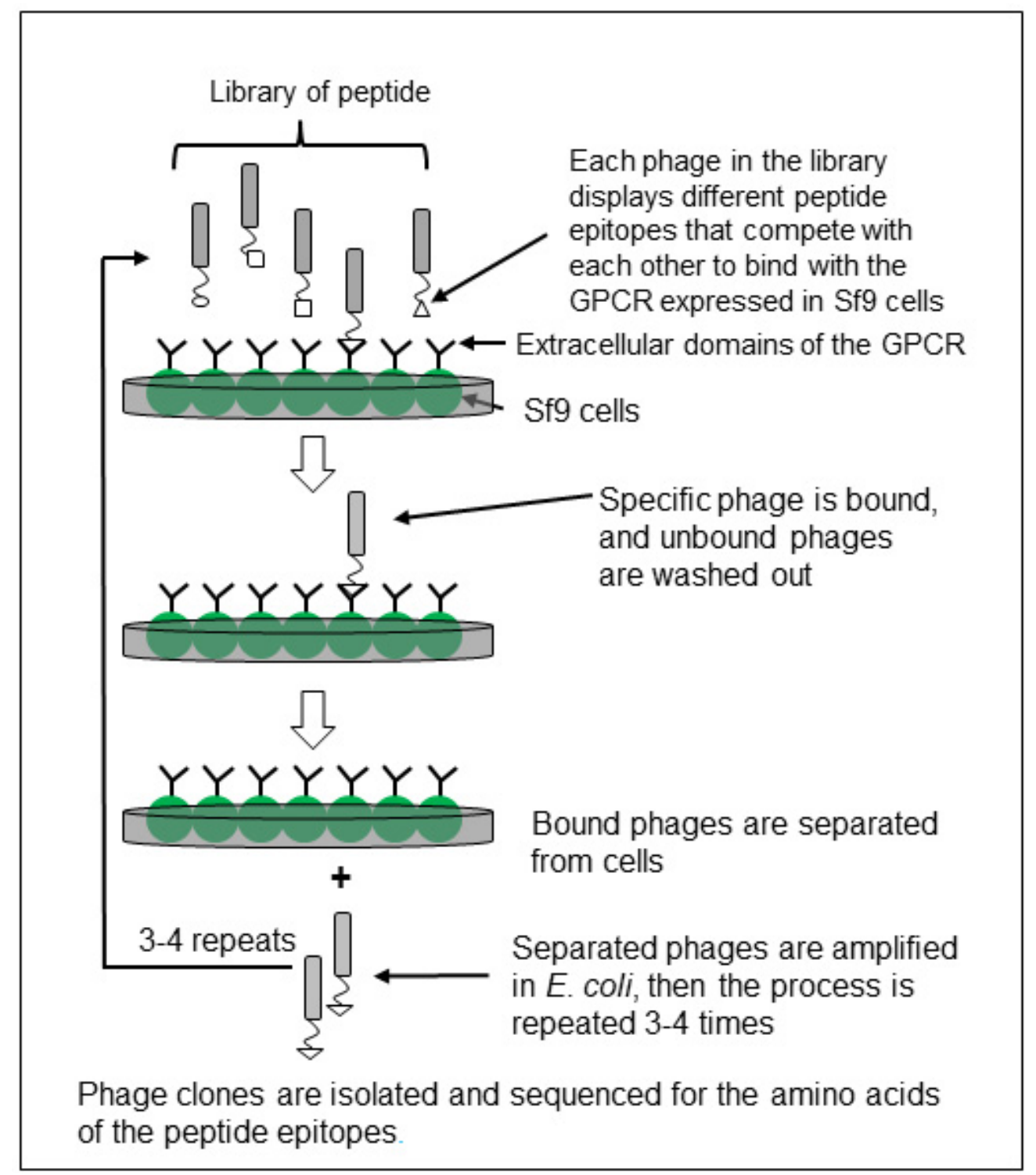

Figure 1. A schematic diagram of GPCR (G-Protein-Coupled Receptor) based screening using a phage display peptide library and biopanning using the insect Sf9 cell expression system. This process requires less than two weeks to obtain amino acid sequences of small peptide molecules after the establishment of functional GPCR expression in the Sf9 insect cell line (see detail in Materials and Methods).

\subsection{Preparation of Phage and Ligand Peptides}

All peptides used in this study were synthesized with more than $95 \%$ purity, to contain an amide group on their C-termini (Peptide 2.0 Inc., Chantilly, VA, USA). Peptides were solubilized in water, aliquoted into 1 to $20 \mathrm{nmol}$ working stocks, dried using a DNA120 SpeedVac Concentrator (Thermo Scientific, Waltham, MA, USA), and frozen at $-20{ }^{\circ} \mathrm{C}$ until use in various assays.

\subsection{Bioassays}

Injection: A selected peptide was injected into the hemocoel of adult ants using a Nanoliter 2000TM System with pulled borosilicate needles (World Precision Instruments, Sarasota, FL, USA). Synthetic peptides $(5 \mathrm{nmol} / 0.1 \mu \mathrm{L})$ were dissolved in a hymenopteran saline (130 mM NaCl, $6 \mathrm{mM} \mathrm{KCl}, 4 \mathrm{mM} \mathrm{MgCl} 2,5 \mathrm{mM} \mathrm{CaCl}_{2}, 160 \mathrm{mM}$ sucrose, $25 \mathrm{mM}$ glucose, and $10 \mathrm{mM}$ HEPES, pH 7.2). The saline was used only for the control. Ants were observed for mortality for 10-16 days post-injection. 
Feeding: Each evaluated peptide was dissolved in a 10\% sucrose solution $(1 \mathrm{mg} / \mathrm{mL})$. Worker ants (250) were randomly selected from a laboratory reared fire ant. The ants were confined in a small plastic cup of which the upper-inside surface was coated with Fluon to prevent them from escaping. Water was provided via a moistened cotton ball throughout the experiment. The ants in the cups were starved for $24 \mathrm{~h}$ prior to introduction of the peptide treatment. Ant bioassay units fed only $10 \%$ sucrose solution served as controls. Ants were observed for mortality for 12 days.

\subsection{Statistical Analysis}

Statistical procedures, e.g., log-rank test survival, and graphical representations were carried out using GraphPad Prism, version 6 (GraphPad Software Inc., San Diego, CA, USA). In some situations, statistical significance was determined by inspection.

\section{Results}

\subsection{Phage Display Library and Biopanning Using Sfg Cell Expression}

Phages bound to the GPCR were then separated, amplified into the host E. coli, and recycled through the process another three times. After the fourth round of the panning selection process, the phage DNAs from randomly chosen clones were sequenced to identify the small peptide epitopes. After the target GPCR was expressed in Sf9 insect cells, the GPCR-based screening process required less than two weeks to isolate and identify small peptides (Figure 1) [21,22].

\subsection{Analysis of Phage-Displayed PEPTIDES Resulting from the Biopanning}

Among 58 phage clones sequenced, the most abundant heptapeptide was identified with the epitope 'QKIGSHF' (19\%, 11 of 58 clones), followed by 'LKIGSHF' (12\%, 7 of 58 clones), then the three epitopes, 'IQQGSHF', 'ERVGSHF', and 'VKLGSHF' (each at 5\%, 3 of 58 clones) (Table 1). Surprisingly, the homology of the peptides gradually changed in their motifs, -KIGSHF, -IGSHF, and - GSHF at the C-terminal end. From all the peptide epitopes, 30 had the tetrapeptide, 'GSHF' (52\%). This number increased to 37 epitopes $(64 \%)$ if serine (S) and threonine (T) are interchanged, GSHF and GTHF (Table 1). The amino acids, $\mathrm{S}$ and $\mathrm{T}$, belong to the same group, having a polar and uncharged functional group. The most abundant dipeptide sequence was ' $\mathrm{HF}^{\prime}$ at the C-terminal end, found in 40 heptapeptides (69\%). Among the 58 heptapeptides, 10 peptide sequences were found at least twice and of these, eight had 'HF' at the C-terminal end. Two peptides, MARYMSA and RGATPMS, had unique sequences compared to the others. None of the selected sequences had any similarity to the peptide sequence of the natural fire ant PBAN ligand, GSGEDLSYGDAYEVDEDDHPLFVPRLamide.

\subsection{Phenotypic Impact of the Novel Peptides on Fire Ants}

The 10 heptapeptides that had at least two identical clones (Table 1) were selected and synthesized with a pair of flanking cysteine residues, thus forming a loop. The first bioassay introduced the peptides into the target fire ant workers via injection, after which the fire ants were observed for phenotypic effects. While injection is not practical as a control method, it is the surest way to get the peptides into the hemolymph of the target ants. Fire ant survival was followed for up to 16 days (Figure 2A-D). Four injected peptides, CQKIGSHFC, CLKIGSHFC, CMARYMSAC, and CRGATPMSC, showed significant impact on fire ant survival compared to the saline control (Log-rank Survival, $p<0.05$ ). However, the other six peptides did not have a significant effect (data not shown). 
Table 1. The peptides screened from the phage display libraries after 3-4 selection rounds are shown. The library heptapeptides are loop-constrained by a pair of flanking cysteine $(\mathrm{C})$ residues. The most abundant amino acids, G, S, H and F, are in green print.

\begin{tabular}{cccc}
\hline $\begin{array}{c}\text { Phage Sequence } \\
\text { (CXXXXXXXC) }\end{array}$ & $\begin{array}{c}\text { Abundance of Phage } \\
\text { Clones }\end{array}$ & $\begin{array}{c}\text { Phage Sequence } \\
\text { (CXXXXXXX) }\end{array}$ & $\begin{array}{c}\text { Abundance of Phage } \\
\text { Clones }\end{array}$ \\
\hline QKIGSHF & 11 & ERVGTHY & 1 \\
\hline LKIGSHF & 7 & IKVGPHY & 1 \\
\hline IQQGSHF & 3 & IKIGSHY & 1 \\
\hline ERVGSHF & 3 & QRIGLHY & 1 \\
\hline VKLGSHF & 2 & VSRTSHL & 1 \\
\hline IVQGSHF & 2 & LPWQIHN & 1 \\
\hline TXVGSHF & 1 & LPMTKHV & 1 \\
\hline IHIGSHF & 1 & TNANHYF & 1 \\
\hline VKQGTHF & 2 & QQTKNYY & 1 \\
\hline TQIGTHF & 1 & SQLPWYS & 2 \\
\hline IQIGTHF & 1 & MARYMSA & 2 \\
\hline QSIGTHF & 1 & RGATPMS & 1 \\
\hline ERVGTHF & 1 & NTGGSMA & 1 \\
\hline IHXGTHF & 1 & NTGSPYE & 1 \\
\hline QSINGHF & 2 & HSRVSGT & 1 \\
\hline YSSPSHF & 1 & TNGDSAR & \\
\hline
\end{tabular}

Two short modifications of the active epitope, CQKIGSHFC, which is the most abundant peptide resulting from the screening process (Table 1 and Figure 2A), were synthesized with flanking cysteine residues (CGSHFC and CHFC) as an initial step toward the investigation of structure-activity relationships. These two short peptides did not elicit significant ant mortality after injection (Figure 3). In addition, the HF peptide without cysteine flanking did not negatively affect ant survival after injection compared to the control (Figure 3). $\mathrm{HF}$ is the most abundant C-terminal dipeptide end sequence found in the peptides isolated from the screening process (Table 1).

Results of the feeding assay with seven peptides showed different survival rates compared to the injection (Figure 4). Only one of seven peptides evaluated, CMARYMSAC, significantly reduced the ant survival rate, $\sim 26 \%$ survival within 6 days. After 6 days, there was no further ant mortality. The other six peptides were not different from the saline control (Figure 4). 
A

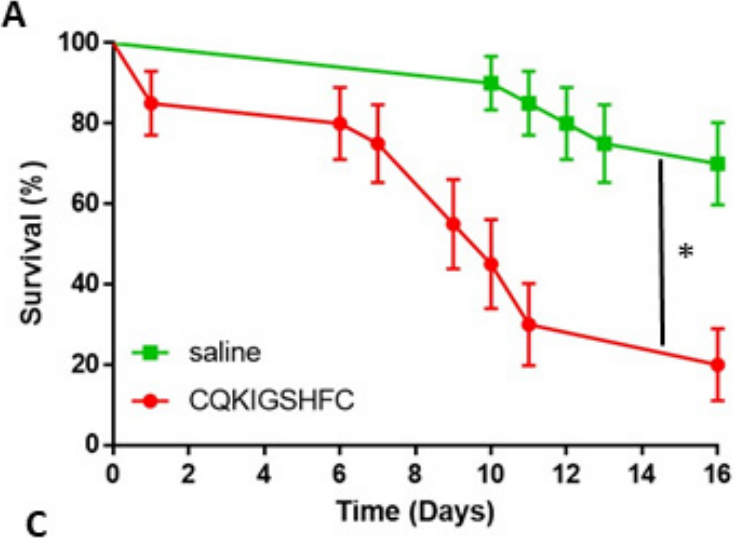

C

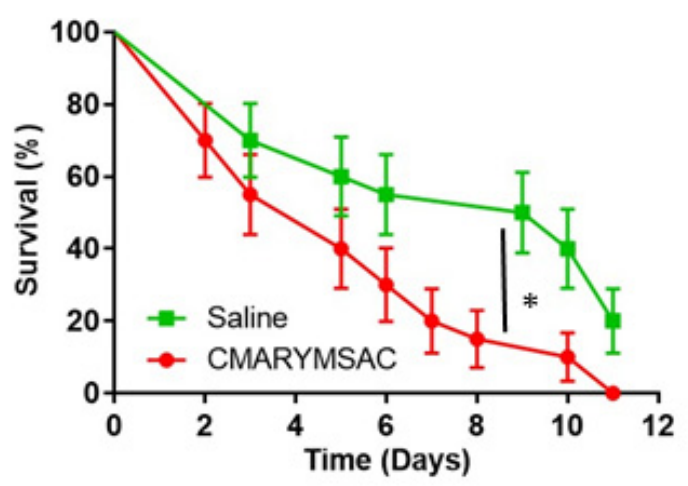

B

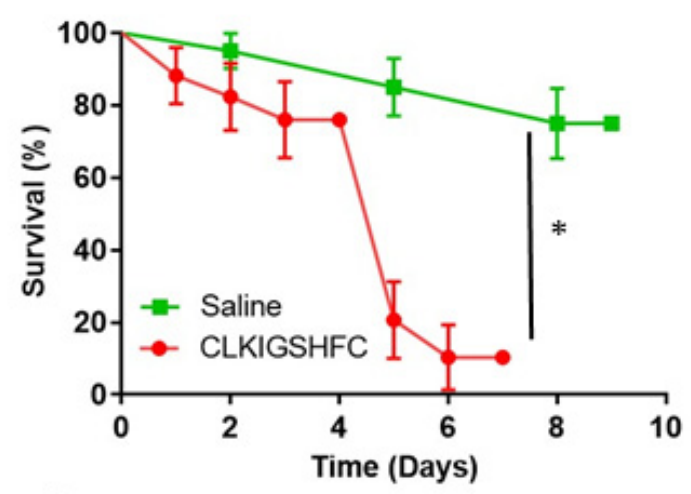

D

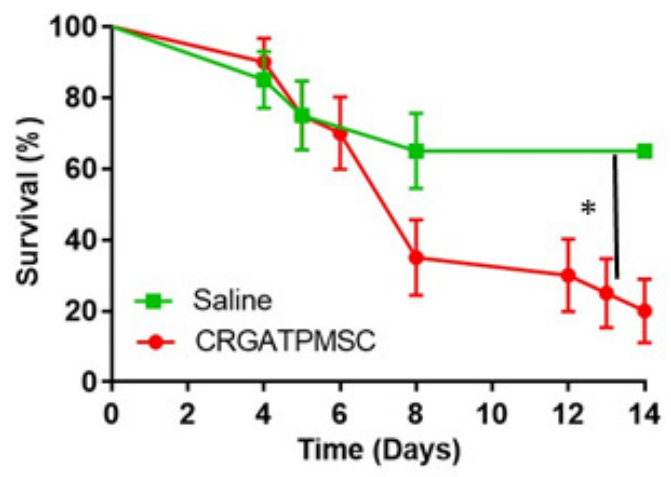

Figure 2. The survival of fire ant workers after injection of synthetic peptides. Saline was injected as a control. An asterisk $(*)$ indicates significant differences by Logrank test $(\mathbf{A})$ CQKIGSHFC $(p=0.0001),(\mathbf{B})$ CLKIGSHFC $(p=0.0001)$; (C) CMARYMSAC ( $p=0.0066)$; (D) CRGATPMSC ( $p=0.0180)$. Survival curves were compared using a standard Log-rank test survival analysis. Each replicate was composed of twenty ants, each treatment/control was replicated three times (mean \pm 3 s.d).

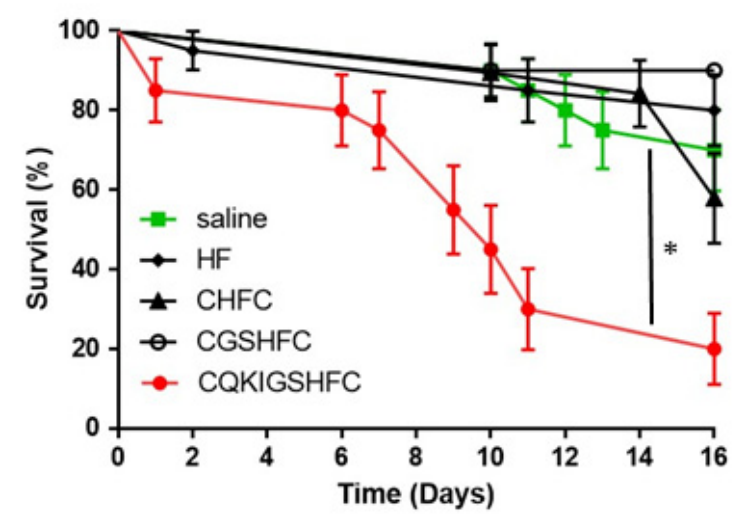

Figure 3. The survival of fire ant workers after injection of the most abundant peptide (CQKIGSHFC) and various short peptides modified from the original epitope. Saline was injected as a control. The asterisk $\left(^{*}\right)$ indicates significant differences by Logrank test (CQKIGSHFC $(p=0.0001)$. Survival curves were compared using a standard Log-rank test survival analysis. Each replicate was composed of twenty ants, each treatment/control was replicated three times (mean \pm 3 s.d). 


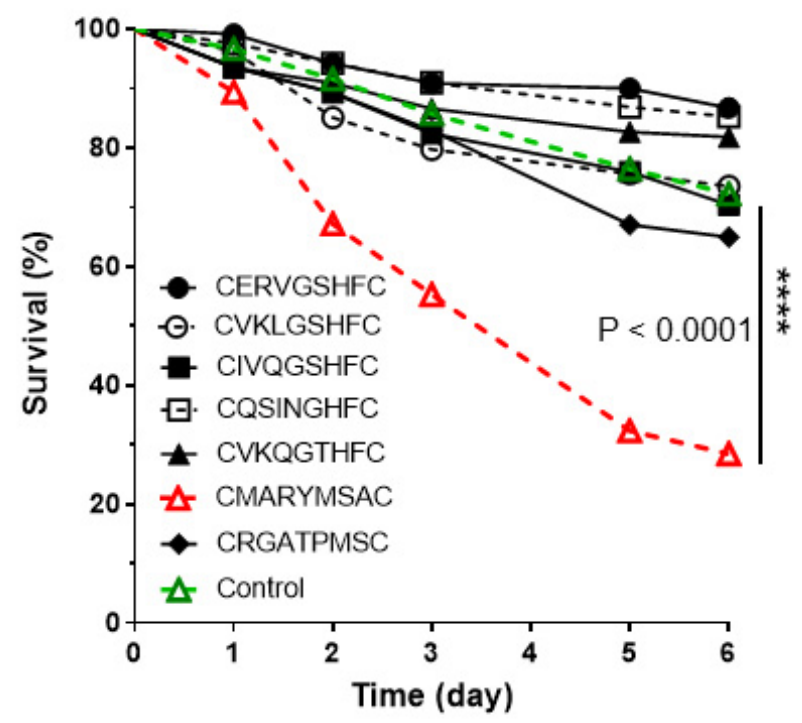

Figure 4. The survival curves of fire ant workers after being fed synthetic peptides. The control was $10 \%$ sucrose solution. Each treatment and the control consisted of 250 workers ants. The peptide, CMARYMSAC, showed $26 \%$ survival after 5 days, and indicates significant differences by a standard Log-rank test. The other peptides showed survival rates that were not different from the saline control. After six days, there was no further ant mortality $\left.{ }^{* * * *}: p<0.0001\right)$.

\section{Discussion}

\subsection{GPCR-Based Screening Using a Library of Phage-Displayed Peptides and Biopanning}

The bacteriophage display library coupled with an insect cell expressing the PBAN GPCR successfully led to the isolation of seven amino acid peptides [23-25]. The peptides in the phage displays are randomly generated to a specific number of amino acids, in our case seven amino acids (CXXXXXXXC where $X$ is any amino acid and $C$ is cysteine), creating a vast library $\left(\sim 2 \times 10^{8}\right)$ of peptide sequences, each of which are exposed on their unique phage surface. The phage display technology has been widely used to isolate proteins, antibodies, cell surfaces, agonists, antagonists, and intracellular proteins in protein-protein interactions [26-28]. The biopanning method uses a differential centrifugation process to separate interactive ligands for drug discovery and gene delivery agents [29-31].

GPCRs are seven transmembrane (7 TM) domain receptors, and are the largest class of cell surface receptors for many key targets in drug development. GPCRs have a structural advantage with the extra cellular binding domains that provide binding pockets for small molecules [32]. The test molecules can be obtained from combinatorial libraries, complex biological mixtures, and/or phage libraries. The common high-throughput screening method for GPCR-based drug discovery uses a variety of chemical libraries, including natural products. Bioactive chemical libraries are commercially available, but they are very expensive (e.g., $\$ 20,000$ per $100 \mu \mathrm{L}$ in $10 \mathrm{mM}$ solution). Therefore, use of the phage libraries (e.g., $\$ 300$ for $\sim 2 \times 10^{10} /$ phage library) and GPCR-based biopanning are more feasible and cost-effective models for novel insecticide discovery.

\subsection{Small Peptides and PRX Peptides}

We expected the strong PBAN binding peptides identified from the phage peptide library to contain the PRX motif. Interestingly, none of the amino acid sequences in the heptapeptides are found in the natural ligand for the PBAN receptor, which for the fire ant, is GSGEDLSYGDAYEVDEDDHPLFVPRL [18,33]. Even the conserved C-terminal -PRX or similar epitope was not found among the 58 peptide epitopes identified. All insect PRX family peptides reported to date have the conserved PRXamide in the C-terminal end $[10,34]$. Therefore, the heptapeptides selected by the methodology in this study may be acting as antagonistic ligands to the GPCR, rather than as agonistic molecules. To evaluate this possibility, we measured the binding activity of each identified peptide to the PBAN 
GPCR expressed in the Sf9 cells. None of these peptides activated extracellular $\mathrm{Ca}^{2+}$ release into the cells, as would be expected for the natural PBAN ligand (data not shown). This result indicates that the isolated phage peptides and the natural ligand are binding to different sites of the GPCR. The phage peptides identified are binding in such a way to either irreversibly change the conformation of the receptor, so the natural ligand cannot bind to the receptor, or the phage peptides are binding with the GPCR and blocking access by the natural ligand. Additional evaluation of antagonistic interactions on the GPCR remains for future research.

The differences in results observed after injection and feeding could be caused by different physiological interactions and the method of delivery to the target receptor. One key factor may be the hydrophobicity of the amino acids in the peptides. In fact, the peptide CMARYMSAC is more hydrophobic than the other peptides and had low water solubility. This characteristic could help this peptide pass from the midgut to the hemolymph, where it can then act on the target receptor. Formulation with lipid-based nanoparticles or modification of the small peptides could increase their impact on ant survival. Degradation of the peptides by midgut enzymes in the ants may also contribute to the feeding results.

\subsection{GPCR-Based Insecticide Discovery: A Proof of Concept and Feasibility}

Most arthropod neuropeptides and their GPCRs have been well conserved during the evolutionary process, and similar molecules are found in vertebrates. Since the first insect GPCR, the diuretic hormone receptor, was discovered from Manduca sexta [35], a variety of GPCRs have been identified from insect genome sequences based on the presence of the well conserved 7 TM regions in GPCRs [11,36,37]. In the Drosophila genome, $\sim 200$ genes (less than $2 \%$ of the total genes) encode for GPCRs, including receptors for neurotransmitters, hormones, olfaction, and taste. Approximately 100 genes have been classified as neurotransmitter and/or hormone GPCRs [36]. GPCRs for neuropeptides (NPs) in the class A family are estimated at only 44 genes based on the fly base [38]. However, the number of functional GPCRs actively translated for insect NPs might be much lower than 44 genes, because many NP GPCRs are known to have multiple variants. The variants are translated, but are not expressed or only marginally expressed. For example, a variety of PRX GPCRs were found with 2-3 variants including silencing receptors [39-43]. Therefore, the total GPCRs for all NPs of target insect pests is a manageable size for GPCR-based insecticide discovery.

Another advantage to NPs as biological targets is that insect NPs have multiple biological functions during insect life stages. One of the best examples is the PRXamide family peptides. The PRXamide peptides have a broad range of physiological functions: (1) stimulation of sex pheromone biosynthesis in female moths [44]; (2) induction of melanization in moth larvae [45]; (3) induction of embryonic diapause in the silkworm [46]; (4) termination of the development of pupal diapause in heliothine moths [47], (5) stimulation of visceral muscle contraction in cockroaches [48]; (6) acceleration of puparium formation in the flesh fly [49], and many unknown functions in other insect groups.

\section{Conclusions}

GPCR-based screening technology for the isolation and identification of bioactive peptides using an insect cell expression system has multiple advantages for the discovery of new insecticides compared to RNAi (Table 2). First, the bioactive peptides act to interfere with the normal binding function of the natural GPCR ligand. We call this mechanism 'receptor interference' (RECEPTORi). It results in negative effect(s) on insect survival. Secondly, potential NP GPCR candidates in total are estimated to include only 20-30 genes, which would promote the rapid screening of all NP GPCRs in the target pest. Thirdly, screening for bioactive peptides is a rapid process. Once the functional expression of the GPCR is established in an insect cell line, it takes less than two weeks to obtain the amino acid sequences of small peptides. Fourthly, delivery of bioactive peptides to target pests can be flexible, e.g., topical, ingestion, or structural modification such as a cyclic form 
with flanking cysteines. They can also be formulated for specific applications, e.g., as plant-incorporated protectants, similar to the Bacillus thuringiensis (Bt) toxin. The ease of using the methodology described here opens up the possibility of developing antagonists for multiple key GPCR functions within a single insect species.

Table 2. Comparison of RECEPTORi and RNAi.

\begin{tabular}{ccc}
\hline Characteristics & RECEPTORi & RNAi \\
\hline Target site & GPCR drive & mRNA drive \\
Mode of action & Interfere receptor & Interfere mRNA \\
Potential target genes & $\sim 400-600$ genes & $\sim 20,000-40,000$ genes \\
Feasible target genes & $\sim 20-30$ genes & $\sim 00$ genes \\
Average molecular weight & $\sim 1-8$ amino acids $(\mathrm{MW}<900)$ & $\sim 21-500$ nucleotides (MW $>13 \mathrm{~K})$ \\
Screening period for targets & Rapid & Slow \\
\hline Delivery method & & Limited due to molecule size \\
- Topical & Available (after formulation) & Available \\
transgenic (plant-incorporated) & Available & Available \\
- Ingestion (oral) & Available & Available \\
- Spraying plant & Available & Limited (synergistic) \\
Bt alternative & Possible & Limited \\
Synthetic mimic (chemical) & Possible & Unlimited \\
Target insect & Unlimited & Possible \\
Biodegradable & Possible (rapid) & Moderate \\
\hline
\end{tabular}

\section{Patents}

There are two patents (U.S. Patent No: 9,771,393 B2 and U.S. Patent No: 10,017,358 B2) resulting from the work reported in this manuscript.

Author Contributions: M.-Y.C. conducted molecular cloning, functional expression, and screening phage peptides. M.-Y.C. and R.K.V.M. performed the peptide injection and feeding bioassays. M.-Y.C. and R.K.V.M. analyzed data and wrote the manuscript. Both authors have read and agreed to the published version of the manuscript.

Funding: This research received no external funding.

Data Availability Statement: No new data were created or analyzed in this study. Data sharing is not applicable to this article.

Acknowledgments: We thank David Milne at USDA-ARS, Gainesville, FL, for technical support and ant colony maintenance.

Conflicts of Interest: The authors declare no conflict of interest.

\section{References}

1. Woods, D.; Butler, C.; Williams, T.; Greenwood, K. Receptor-based discovery strategies for insecticides and parasiticides: A review. Adv. Exp. Med. Biol. 2010, 692, 1-9.

2. Meyer, J.M.; Ejendal, K.F.; Avramova, L.V.; Garland-Kuntz, E.E.; Giraldo-Calderon, G.I.; Brust, T.F.; Watts, V.J.; Hill, C.A. A 'genome-to-lead' approach for insecticide discovery: Pharmacological characterization and screening of Aedes aegypti D(1)-like dopamine receptors. PLoS Negl. Trop. Dis. 2012, 6, e1478. [CrossRef]

3. Grimmelikhuijzen, C.J.; Cazzamali, G.; Williamson, M.; Hauser, F. The promise of insect genomics. Pest Manag. Sci. 2007, 63, 413-416. [CrossRef]

4. Geary, T.G. Nonpeptide ligands for peptidergic G protein-coupled receptors. Adv. Exp. Med. Biol. 2010, 692, 10-26. [CrossRef]

5. Nassel, D.R.; Zandawala, M. Recent advances in neuropeptide signaling in Drosophila, from genes to physiology and behavior. Prog. Neurobiol. 2019, 179, 101607. [CrossRef] [PubMed]

6. Caers, J.; Verlinden, H.; Zels, S.; Vandersmissen, H.P.; Vuerinckx, K.; Schoofs, L. More than two decades of research on insect neuropeptide GPCRs: An overview. Front. Endocrinol. 2012, 3, 151. [CrossRef] [PubMed]

7. Yeoh, J.G.C.; Pandit, A.A.; Zandawala, M.; Nassel, D.R.; Davies, S.A.; Dow, J.A.T. DINeR: Database for insect neuropeptide research. Insect Biochem. Mol. Biol. 2017, 86, 9-19. [CrossRef] 
8. Audsley, N.; Down, R.E. G protein coupled receptors as targets for next generation pesticides. Insect Biochem. Mol. Biol. 2015, 67, 27-37. [CrossRef]

9. Altstein, M.; Nassel, D.R. Neuropeptide signaling in insects. Adv. Exp. Med. Biol. 2010, 692, 155-165. [CrossRef]

10. Jurenka, R. The PRXamide neuropeptide signalling system: Conserved in animals. Adv. Insect Physiol. 2015, 49, 123-170. [CrossRef]

11. Hewes, R.S.; Taghert, P.H. Neuropeptides and neuropeptide receptors in the Drosophila melanogaster genome. Genome Res. 2001, 11, 1126-1142. [CrossRef]

12. Vanden Broeck, J. Insect G protein-coupled receptors and signal transduction. Arch. Insect Biochem. Physiol. 2001, 48, 1-12. [CrossRef]

13. Park, Y.; Kim, Y.J.; Adams, M.E. Identification of G protein-coupled receptors for Drosophila PRXamide peptides, CCAP, corazonin, and AKH supports a theory of ligand-receptor coevolution. Proc. Natl. Acad. Sci. USA 2002, 99, 11423-11428. [CrossRef] [PubMed]

14. Howard, A.D.; Wang, R.; Pong, S.S.; Mellin, T.N.; Strack, A.; Guan, X.M.; Zeng, Z.; Williams, D.L., Jr.; Feighner, S.D.; Nunes, C.N.; et al. Identification of receptors for neuromedin U and its role in feeding. Nature 2000, 406, 70-74. [CrossRef] [PubMed]

15. Choi, M.Y.; Vander Meer, R.K.; Coy, M.; Scharf, M.E. Phenotypic impacts of PBAN RNA interference in an ant, Solenopsis invicta, and a moth, Helicoverpa zea. J. Insect Physiol. 2012, 58, 1159-1165. [CrossRef]

16. Choi, M.Y.; Vander Meer, R.K. Phenotypic effects of PBAN RNAi using oral delivery of dsRNA to corn earworm (Lepidoptera: Noctuidae) and tobacco budworm larvae. J. Econ. Entomol. 2019, 112, 434-439. [CrossRef]

17. Lu, Q.; Huang, L.Y.; Chen, P.; Yu, J.F.; Xu, J.; Deng, J.Y.; Ye, H. Identification and RNA Interference of the pheromone biosynthesis activating neuropeptide (PBAN) in the common cutworm moth Spodoptera litura (Lepidoptera: Noctuidae). J. Econ. Entomol. 2015, 108, 1344-1353. [CrossRef]

18. Choi, M.Y.; Vander Meer, R.K. Ant trail pheromone biosynthesis is triggered by a neuropeptide hormone. PLoS ONE 2012, 7, e50400. [CrossRef]

19. Banks, W.A.; Lofgren, C.S.; Jouvenaz, D.P.; Stringer, C.E.; Bishop, P.M.; Williams, D.F.; Wojcik, D.P.; Glancey, B.M. Techniques for Collecting, Rearing, and Handling Imported Fire Ants; AAT-S-21; USDA Science and Education Administration: New Orleans, LA, USA, 1981; 9p.

20. Choi, M.Y.; Fuerst, E.J.; Rafaeli, A.; Jurenka, R. Identification of a G protein-coupled receptor for pheromone biosynthesis activating neuropeptide from pheromone glands of the moth Helicoverpa zea. Proc. Natl. Acad. Sci. USA 2003, 100, 9721-9726. [CrossRef]

21. Choi, M.Y; Vander Meer, R.K. Bioactive Peptides Having Insecticide Activity. U.S. Patent 9771393B2, 26 September 2017.

22. Choi, M.Y.; Vander Meer, R.K. Bioactive Peptides Having Insecticides Activity. U.S. Patent 10017358B2, 10 July 2018.

23. Parmley, S.F.; Smith, G.P. Antibody-selectable filamentous fd phage vectors: Affinity purification of target genes. Gene 1988, 73, 305-318. [CrossRef]

24. Christianson, D.R.; Ozawa, M.G.; Pasqualini, R.; Arap, W. Techniques to decipher molecular diversity by phage display. Methods Mol. Biol. 2007, 357, 385-406. [CrossRef]

25. Scott, J.K.; Smith, G.P. Searching for peptide ligands with an epitope library. Science 1990, 249, 386-390. [CrossRef]

26. Azzazy, H.M.; Highsmith, W.E., Jr. Phage display technology: Clinical applications and recent innovations. Clin. Biochem. 2002, 35, 425-445. [CrossRef]

27. Sidhu, S.S.; Fairbrother, W.J.; Deshayes, K. Exploring protein-protein interactions with phage display. ChemBioChem 2003, 4, 14-25. [CrossRef] [PubMed]

28. Molek, P.; Strukelj, B.; Bratkovic, T. Peptide phage display as a tool for drug discovery: Targeting membrane receptors. Molecules 2011, 16, 857-887. [CrossRef]

29. Giordano, R.J.; Cardo-Vila, M.; Lahdenranta, J.; Pasqualini, R.; Arap, W. Biopanning and rapid analysis of selective interactive ligands. Nat. Med. 2001, 7, 1249-1253. [CrossRef]

30. Sergeeva, A.; Kolonin, M.G.; Molldrem, J.J.; Pasqualini, R.; Arap, W. Display technologies: Application for the discovery of drug and gene delivery agents. Adv. Drug Deliv. Rev. 2006, 58, 1622-1654. [CrossRef]

31. Ghosh, A.K.; Ribolla, P.E.; Jacobs-Lorena, M. Targeting Plasmodium ligands on mosquito salivary glands and midgut with a phage display peptide library. Proc. Natl. Acad. Sci. USA 2001, 98, 13278-13281. [CrossRef]

32. Wess, J. Molecular basis of receptor/G-protein-coupling selectivity. Pharmacol. Ther. 1998, 80, 231-264. [CrossRef]

33. Choi, M.Y.; Vander Meer, R.K. Identification of a new member of the PBAN family of neuropeptides from the fire ant, Solenopsis invicta. Insect Mol. Biol. 2009, 18, 161-169. [CrossRef] [PubMed]

34. Rafaeli, A. Pheromone biosynthesis activating neuropeptide (PBAN): Regulatory role and mode of action. Gen. Comp. Endocrinol. 2009, 162, 69-78. [CrossRef]

35. Reagan, J.D. Expression cloning of an insect diuretic hormone receptor. A member of the calcitonin/secretin receptor family. J. Biol. Chem. 1994, 269, 9-12. [CrossRef]

36. Brody, T.; Cravchik, A. Drosophila melanogaster G protein-coupled receptors. J. Cell Biol. 2000, 150, F83-F88. [CrossRef]

37. Adams, M.D.; Celniker, S.E.; Holt, R.A.; Evans, C.A.; Gocayne, J.D.; Amanatides, P.G.; Scherer, S.E.; Li, P.W.; Hoskins, R.A.; Galle, R.F.; et al. The genome sequence of Drosophila melanogaster. Science 2000, 287, 2185-2195. [CrossRef] 
38. FlyBase. D. Melanogaster GPCR. Available online: http:/ / flybase.org/ (accessed on 2 February 2020).

39. Lee, J.M.; Hull, J.J.; Kawai, T.; Goto, C.; Kurihara, M.; Tanokura, M.; Nagata, K.; Nagasawa, H.; Matsumoto, S. Re-evaluation of the PBAN receptor molecule: Characterization of PBANR variants expressed in the pheromone glands of moths. Front. Endocrinol. 2012, 3, 6. [CrossRef] [PubMed]

40. Nusawardani, T.; Kroemer, J.A.; Choi, M.Y.; Jurenka, R.A. Identification and characterization of the pyrokinin/pheromone biosynthesis activating neuropeptide family of $\mathrm{G}$ protein-coupled receptors from Ostrinia nubilalis. Insect Mol. Biol. 2013, 22, 331-340. [CrossRef]

41. Jiang, L.; Zhang, F.; Hou, Y.; Thakur, K.; Hu, F.; Zhang, J.G.; Jiang, X.F.; Liu, Y.Q.; Wei, Z.J. Isolation and functional characterization of the pheromone biosynthesis activating neuropeptide receptor of Chinese oak silkworm, Antheraea pernyi. Int. J. Biol. Macromol. 2018, 117, 42-50. [CrossRef]

42. Luo, M.; Zhou, X.C.; Wang, Z.; Chen, J.X.; Chung, H.; Wei, H.Y. Identification and gene expression analysis of the pheromone biosynthesis activating neuropeptide receptor (PBANR) from the Ostrinia furnacalis (Lepidoptera: Pyralidae). J. Insect Sci. 2019, 19, 25. [CrossRef]

43. Ahn, S.J.; Corcoran, J.A.; Vander Meer, R.K.; Choi, M.Y. Identification and characterization of GPCRs for pyrokinin and capa peptides in the brown marmorated stink bug, Halyomorpha halys (Hemiptera: Pentatomidae). Front. Physiol. 2020, 11, 559. [CrossRef] [PubMed]

44. Raina, A.K.; Jaffe, H.; Kempe, T.G.; Keim, P.; Blacher, R.W.; Fales, H.M.; Riley, C.T.; Klun, J.A.; Ridgway, R.L.; Hayes, D.K. Identification of a neuropeptide hormone that regulates sex pheromone production in female moths. Science 1989, 244, 796-798. [CrossRef] [PubMed]

45. Matsumoto, S.; Kitamura, A.; Nagasawa, H.; Kataoka, H.; Orikasa, C.; Mitsui, T.; Suzuki, A. Functional diversity of a neurohormone produced by the suboesophageal ganglion: Molecular identity of melanization and reddish colouration hormone and pheromone biosynthesis activating neuropeptide. J. Insect Physiol. 1990, 36, 427-432. [CrossRef]

46. Suwan, S.; Isobe, M.; Yamashita, O.; Minakata, H.; Imai, K. Silkworm diapause hormone, structure-activity relationships indispensable role of C-terminal amide. Insect Biochem. Mol. Biol. 1994, 24, 1001-1007. [CrossRef]

47. $\mathrm{Xu}, \mathrm{W} . \mathrm{H} . ;$ during diapause, and a new role for diapause hormone. Insect Mol. Biol. 2003, 12, 509-516. [CrossRef] [PubMed]

48. Predel, R.; Nachman, R.J. Efficacy of native FXPRLamides (pyrokinins) and synthetic analogs on visceral muscles of the American cockroach. J. Insect Physiol. 2001, 47, 287-293. [CrossRef]

49. Zdarek, J.; Nachman, R.J.; Hayes, T.K. Insect neuropeptides of the pyrokinin/PBAN family accelerate pupariation in the fleshfly (Sarcophaga bullata) larvae. Ann. N. Y. Acad. Sci. 1997, 814, 67-72. [CrossRef] [PubMed] 